\title{
CONSTITUTIONAL SOCIAL RIGHTS WITHOUT A SOCIAL SECURITY PHILOSOPHY ${ }^{1}$
}

\section{Carlos Luiz Strapazzon}

Professor of Constitutional Law. Professor of the Fundamental Rights Program at the Western University of Santa Catarina State School of Law, UNOESC, in Chapecó-SC State, where heads a Line of research on social rights. Editor-in-Chief of the EJJL (2011-2016). I am also Professor of Constitutional Law at University Positivo School of Law in Curitiba, Paraná State. Contact: <strapazzon.carlos.luiz@gmail.com>. Author of parts 1-2 and 8; co-author of the parts 3 to 7 , as well as conclusions.

\section{Robison Tramontina}

Professor of Philosophy of Law at the Fundamental Rights Program at the Western University of Santa Catarina State School of Law, UNOESC, in Chapecó, Brazil, where heads a Group of Research Fundamental Rights and Philosophy of Justice along with responsabilities of supervising students. Editor-Assistent of the EJJL (2013-2016), a scientific Journal dedicated to fundamental constitutional rights. Co-author of the parts 3 to 7, as well as conclusions. Contact: <robison.tramontina@unoesc.edu.br>.

\begin{abstract}
Brazilian constitutional law has a broad and multidimensional conception of fundamental rights. The so-called Welfare Rights are part of them. They are not only formally grounded on Title II, the Bill of Fundamental Rights, but are also protected by particular Constitutional Actions established as means for judicial implementation thereof. Welfare Rights as healthcare, social insurance and social care services for the most vulnerable, enjoy, therefore, a preferential position within the Brazilian system of constitutional rights. This article maintains that in spite of adopting a strong constitutional framework for healthcare, social insurance and socialcare services, the lack of a consistent and coherent political philosophy for welfare state seriously undermine the progressive implementation of these constitutional rights. In the first part the manuscript seeks to clarify the causes of this circumstance of recognition of health, socialcare and social insurance as fundamental rights without equivalent recognition of social security as a proper human right. Afterwards, the article is particularly concerned with the features of the judicialization of social rights. As a matter of conclusion, the article points out this situation as a paradox by addressing the lack of a proper philosophy of social security in a context of strong constitutional protection for health, social insurance and social care services.
\end{abstract}

Keywords: Social Security. Welfare State. Social Rights. Brazil.

Summary: 1 Introduction - $\mathbf{2}$ Broad conception of social rights, narrow consensus on social security $\mathbf{3}$ Judicial review in the political arena $\mathbf{- 4}$ Slavery - $\mathbf{5}$ Collective labour rights $\mathbf{- 6}$ Access to medicines: blocking public budget and joint responsibility of federal entities - $\mathbf{7}$ Equipment and materials for hospitals - $\mathbf{8}$ Day-care centers and pre-schools - $\mathbf{9}$ Social insurance rights - $\mathbf{1 0}$ Conclusions - References

1 Acknowledgements are due our Universities, given that writing and translation this article was only possible with the financial support of UNOESC and Universidade Positivo (for Carlos Luiz Strapazzon). The author of the parts 1-2; 7-9 is Carlos Luiz Strapazzon. Professor Dr. Robison Tramontina, has participated in the selection of cases as well as with the writing of the 3th up to 6th parts of this paper. 


\section{Introduction}

Needless to say that Social Security is widely spread as a public aim to be achieved through a model of universal healthcare, social care and social insurance, fully coordinated by the State (ESPING-ANDERSEN, 2012; HEREDERO 2007; ILO 2011; UNRISD - United Nations Research Institute for Social Development, 2006). Moreover, contemporary approaches highlight that it is a thin simplification reducing Social Security to a mere system of institutions: rather, it is first and foremost, a human right that is to be implemented via a system of institutions and policies which work as tools for such a human right (ILO, 2001; ILO, 2011; ISSA, 2013; ABRAMOVICH; COURTIS, 2011; HEREDERO 2007; LANGFORD, 2009).

Conversely, and in spite the fact that in Brazil there is a vast legal literature upon social security and fundamental rights (SAVARIS, 2011; SARLET, 2012; FLEURY 2005; FLEURY,1994; IPEA 2008), it is quite rare to see acknowledgments of social security itself as a fundamental human right. Rather, the opposite is more likely to be the case, once the most part of brazilian scholars (CASTRO; LAZZARI 2015, p.27-28), politicians, even the Courts, tend to see social security as a system of institutions charged with the implementation of health, social assistance and social insurance policies. In spite of the fact that all these mentioned human rights are oftenly seen as means to the enforcement of those three fundamental human rights, such cornerstones are not properly admited as means for the realization of social security as an autonomous right in itself.

This paper draws attention to the Brazilian theory on social security, particularly within the legal and constitutional realm. The paper argues that the dominant view takes the parties as fundamental rights, though without confering the same legal status to the whole: the right to social security. Therefore, we maintain this is a paradox with two main causes: on the one hand, to the poor development of a philosophy of social security in Brazil, particularly because huge dissensions on the role of social security inside this complex society. Secondly, because of the capture of the public debate on social security by the Constitution, which has sparked a strong judicialization of the political arena as one of the most outstanding outcomes.

Thus, in the first part the manuscript seeks to clarify the causes of this circumstance of recognition of health, social care and social insurance as fundamental rights without equivalent recognition of social security as a proper human right. Afterwards, the article is particularly concerned with the features of the judicialization of social rights. As a matter of conclusion, the article points out this this situation as a paradox by adressing the lack of a proper philosophy of social security as an outcome of a political dissent within the social conflict in Brazil. 


\section{Broad conception of social rights, narrow consensus on social security}

We assume that the line of research in constitutional social security is crucial for further advancements in the field of fundamental rights theory in Brazil actually, one might say that it is also the case for the Latin America as a whole. The clarification of this particular human right, namely, its existence, scope and significance for all the rest of constitutional rights, as well as its costs and benefits are not only of utmost political, but also theoreticaly significant.

Accordingly, it is fair to hold that if Brazil has not yet a strong dialogue between human rights theory, fundamental social rights theory along with the welfare state theory - that is, a dialogue which appropriately entail knowledges on social policy, labor market, household care and civil society along with the most recent understandings on human rights, human development and constitutionalism - it might be partly due to the lack of lines of research in the field of social security in Brazilian Schools of Law and partly because of the fragile political consensus upon this issue.

Thus, from this point of view, there are scientific and political reasons reinforcing their own weakness. To put in other words, the lack of a scientific culture of investigating welfare rights as human rights negatively affects political and legal understandings on the scope of fundamental rights and thereby significantly complicates the achievement of political consensus. On the other hand, Brazilian constitution is one of the most devoted to social rights. That means the Constituent was strongly confident on the role of the Judicial Branch as a guardian of its undertaking.

During the course of the last years we have been attempting to address this crucial conceptual research (STRAPAZZON, 2015; STRAPAZZON, 2012; STRAPAZZON; SERRAMALERA, 2013) based on the conviction that if Brazil has strongly innovated in its constitutional design concerning welfare rights, constitutional theory has not been developed at the same pace. However, this is in part a matter of a shortfall withing the constitutional theory.

It is quite clear that in Brazil one of the fields of law most affected by legal disputes after 1988 is precisely that one regarding welfare fundamental rights. This is so partly because welfare rights are formally enshrined in the Article 6 of the Brazilian Constitution, Title II, which recognizes them as Fundamental Rights. Moreover, the Constitution protects these rights through strong Actions labeled Constitutional Guarantees. Based on these reasons, it is undeniable that welfare rights are formally part of the Brazilian Bill of Rights. This means they occupy a prominent position within the system of constitutional rights, since all rights formally established in Title II have a relative predominance over all others. 
By contrast, the Brazilian model of Constitutional Law embraces a broad and multidimensional conception of fundamental rights. This can be clearly observed not only by a quick glance to the text as such, which acknowledge individual and collective rights, freedom, equality and fraternity rights, civil and political rights, social, economic and cultural rights as well as rights for the future generations, such as enviromental rights. Furthermore, the principle of dignity of all human beings is one of the cornestones of this text, as an aim for the Republic as a whole. In spite of this, the Chart is also an open system for new rights, since it provides the traditional overture to unenumerated rights. ${ }^{2}$ Lastly, it is of immense significance the role of Supreme Court in this framework: it is, from a formal point of view, the Guardian of this constitutional system.

In conclusion, Brazilian constitution embraces a large number of rights, with a broad and multidimensional perspective, which by one hand reveals a sharp decision to modernize and reform the public sphere by a transition from militar dictatorship system towards a constitutional democracy. As far as the Courts are concerned, this model strongly reshaped the democratic conflict by legitimating a huge interventions by the Judicial Branch into the political arena.

Regarding the welfare rights, the Brazilian Constituent has assured an outstanding presence for them in the Chart. The constitutional right to social security, for instance, is undoubtedly the most itemized one among all latin american larger democracies as well as among the countries from BRICS. ${ }^{3}$

The issue of health, for example, is mentioned 57 times by the Constitution. It appears in the form of general fundamental right (Art. 6), then, as a special constitutional law (Art. 196), as a special freedom to private enterprise, but limited to the national capital (Art. 199, §3), as a special right of children, youth and adolescents (Art 227); as a special right of employment relationships, it appears as a mandatory element of the scope of protection of the purchasing power of the minimum wage (Article 7, IV.), as a limit for risks in the workplace (Article 7, XXII.); as a limit to the freedom of expression advertising (Article 220, §3, II.); as

2 Article 5 (2) states that: "The rights and guarantees expressed in this Constitution do not exclude others deriving from the regime and the principles adopted by it, or from the international treaties to which the Federal Republic of Brazil is a party"; and paragraph 3 of the same article affirms that "The international treaties and conventions on human rights that are approved, in every House of the National Congress, in two rounds, by three-fifths of the votes of its members"; and finally, it acknowledges in Article 7 a catalogue of open-ended fundamental rights of work; however, recognizing that "they are rights of urban and rural workers, in addition to others that aim at the improvement of their social condition."

3 This is an outcome of a new empirical research which offer details on the itemization of welfare rights in 20 countries (Canada, Australia, Japan and US; Germany, France, Italy, Spain and Poland; Norway, Sweden; Mexico, Colombia, Argentina, Chile; Brasil, Russia, India, China and South Africa): Strapazzon, C. L. The human right to social security: the brazilian constitutional regime compared to 20 foreign models. Journal of IBDP, 2016, forthcoming issue. 
administrative and legislative duty of all federal units (Article 23, II, Article 24, XII and Article 30, VII), as a priority public policy (Art. 34, VII, e; Art. 35, e; Art. $166 \S 90$ e 10o, Art. 167, IV, Art. 198 §2o); as a condition to get special type of retirement benefit (Article 40, §4, III.), as a special law arrangement for public policies on social security (Art 194.); as the right to be assisted by the special social security budget (Article 195, §2.); as a right that requires the creation of a special administrative framework, called the Unified Health System (Art. 198, Art. 200).

In turn, the right of income protection through social insurance mechanisms appears connected to the concept of pension benefits as well as the social assistance rights. Both are as much itemized as the right to health. They are fundamental rights (Art 6), and autonomous constitutional rights (Art. 201, Art. 203). Pension benefits are described as a special right of employment relationships, since it is compulsory to protect the minimum wage's purchasing power (Art. 7, IV, Art. 201, §11). Moreover, it is a special right to domestic workers (Art. 7, § single, Article 201, §12); a special collective right for unionized workers (Art. 10); a special right to public servants (Article 40); they are an Union administrative competence (Article 21, VIII); but there is a legislative competence for all the federal units (Article 24, XII); they are a limit to the budgetary policy (Article 167, $\mathrm{XI}$.); and an instrument of economic policy (Article 179). They are part of the public policies arrangement for social security (Art 194), which means, among others, the right to be assisted by the special social security budget (Art. 195, §2).

The right to social assistance (or collective assistance or social care) was established as a particular fundamental right to those who live under particular circumstance of social vulnerability (which was equivocally labeled by the Art. 6 as "helpless people," and by the Art. 203 as "needy people"). It is noteworthy that the Constitution prescribes a particular duty to the State of paying a benefit (a minimum wage) to elderly and persons with a disability who prove to be unable to afford their own support or having it afforded by the household, according to the law (Article 203, V.). Furthermore, socialcare is also treated as a special right of the array of public policies for social security (Art. 194), as a right to be assisted by the special social security budget (Art. 195, §2), as a service that can be provided by non- governmental organizations (Article 195, IV, §7.); as a public policy competence of all federal units (Art. 195, IV, §10) to be carried out with the resources of the special budget of social security (Art. 204).

It is of particular interest to clarify that by opting for a long and meticulous set of written social rights as well as for an open approach to fundamental rights, the Constituent (1988) assumed to be doing simply the basic floor, that is, the first step for the new democracy. That is to say that a so deeply analytic text shall not in any way whatsoever be interpreted as a final work. Further political articulation 
would be necessary. Therefore, the Constituent decision of enlarging the Bill of Rights is full of significance for the political conflict Brazil has been addressing over the last three decades. It sounds as if from 1988 onwards the main issues of the political realm had been moved from the democratic arena to the legal one; furthermore, as if citizenship has become synonym of being interpreter of the Constitution.

Considering Latin America contemporary history, one may suppose that the option for this prominent position of itemizing human dignity and fundamental social rights in a Constitution might be explained as a democratic reaction against a conservative society used with dictatorship, torture, slavery, genre inequality and many other expressions of violations to human dignity. After all, and unfortunately, all these practices have been very common within Latin American societies.

In spite of being somehow appropriate, this view does not take the whole landscape. Even though part of constitutional changes may be explained in terms of a political reaction against uncivilized common practices of the past, there were others interests at stake: the universalization of citizenship was the pivotal one. Indeed, neither dignity, nor fundamental rights were more important than citizenship for the Brazilian constitucional transition in the end of the 80's. Nonetheless, citizenship was meant not only in terms of freedom from dictatorship or direct elections, but also as an aim to be achieved through a broad conception of social rights. ${ }^{4}$ Therefore, one must not set aside these two ambitions of the Brazilian democratic transition: overcome autocratic governments along with enlarging the meaning of citizenship by adding social rights in the scope of citizenship. In fact, once one is aware of this second ambition it becomes easier to understand why a compatible welfare philosophy toward interpreting this Constitution is of utmost significance.

If the implementation of the constitutional human right of social security has claimed a huge reinvention of the public institutional design set forth in the Constitution, in order to enforce the new perspective of constitutional rights, it has also raised up huge political and theoretical dissents no less challenging. For instance, as a matter of fact, Brazilian constitutional theory has been engaged with a dialogue with human rights very recently, no more than twenty years ago (PIOVESAN 1996). Notwithstanding, even today it is widely spread within Brazilian theory of law that an almost pure dissociation between constitutional and human rights should be admitted, even though grounded on predominantly formal reasons (SARLET, MARINONI, MITIDIERO 2016, p. 300-303).

\footnotetext{
4 The content of such rights is stated by the Article 6 of the Charter. Education, health, food, work, housing, transportation, leisure, security, pension rights, protection of motherhood and childhood, and assistance to the most vulnerable are social rights, as set forth by this Constitution.
} 
Apart these theoretical challenges, there is a wide acceptance of the fact that these are times of both economic and political structural changes that profoundly affected the aspiration of universal coverture of welfare rights. There have been setbacks across the world resulting from fiscal adjustments initiated from 2010 onwards. For instance, "in 2014, 122 countries are limiting their public expenditures in terms of GDP, at a time when populations are most in need" (ILO 2014, 5).

While is on the way a new era of low rate of economic growth with increasing of productivity and innovation, along with higher levels of uncertainty and unemployment, human rights approach has transformed itself. From a system of positive fundamental rights to a set of tools concerned with a new approach inside this new scenario. That is why enlarging human capabilities, reducing inequalities in order to create more resilient societies within a sustainable development enviroment is nowadays the path for the realization of human rights (UNITED NATIONS 2015, p.16).

These different sides of the picture might well indicate that both the theoretical as well as empirical research on social security human rights ask for a new kind of constitutional approach to welfare rights. A new approach for social security rights must be able to explain the necessary reinterpretation of the right to health care, social care and pensions benefits driven not only by the principles of citizenship or dignity, but also in harmony with the challenges that are arising in the wake of the crisis of 2012: social security rights have now to be seen as a tool for building more resilient societies, more equitable, more free, more inovatives in order to help national and global recovery based on a sustainable human development.

To summarize: these are times of great complexity, a moment that claims not only for scientific innovation so as to enhance existing ties between social security, constitutional ideals and new assumptions that comes from the new global agenda. It is also extremely necessary to consolidate a new philosophy for the constitutional right to healtcare, socialcare and social insurance as rights implied with the social security human right, which is a tool for the enlargement of To summarize: these are times of great complexity, a moment that claims not only for scientific innovation so as to enhance existing ties between social security, constitutional ideals and new assumptions that comes from the new global agenda. It is also extremely necessary to consolidate a new philosophy for the constitutional right to healthcare, socialcare and social insurance as rights implied with the social security human right, which is widely recognized as pivotal tool to the enlargement of human capabilities, to decreasing inequalities and to creating more resilient societies.

Now, it is also important to take note that over the course of last years, democratic mechanisms were not very much developed in Brasil in order to develop 
this new agenda. Putting this in better words, not as much as Brazilians expected so as to achieve the constitutional aims within this new context. In reality, up to now Brazilian society could not overcome old prejudices with basic republican values, namely, equal worth of every person, freedom of press and the need to clearly separate state and private interests. ${ }^{5}$ Thus, during the last 28 years, the theme of human development, universal health protection and livelihood were poorly addressed whether it is by the state or by the civil society, despite the very good outcomes of the period 2002-2012.

Considering the first 15 years of political transition (1988-2003), the public agenda remained heavily concentrated on fiscal reforms so as to combat hyperinflation and reducing public spending, which were critical concerns for recovery of growth, though. If during the last 10 years (2003-2013) the issue of erradication of extreme poverty, child mortality, nutrition, health care, sanitation, decent work, full employement, housing, education, equal citizenship were taken as a priority, notwisthstanding, both of these periods were based on fragile political consensus upon the significance and the role of social security for the economic recovery as well as for the building of a more resilient and sustainability society. Quite on the contrary, social security has been seen far more as a mechanism of relieving human suffering.

If political dissension has contributed to the failure in innovating and creating a strong democratic arena with active engagement of civil society in Brazil during the 90's and later on, alternatively Brazilian Constitution as seen above have strengthened the political role of the Judicial Branch as the stage where social conflicts should be addressed.

It is not by chance that several institutional and procedural innovations were created in order to protect the new set of fundamental rights, but eventually it has strengthened the so-called "judicialization of politics". It is quite clear today that the main features of this judicial empowerment stems primarily from the long list of fundamental rights set forth in the Constitution; secondly, it has also to do with the expansion of the Supreme Court power to realize several forms of concentrated judicial reviews - somehow following the Austrian and German model - along with new ways of dialogs with civil society, through public hearings and amicus curiae mechanisms. ${ }^{6}$ Furthermore, a new design for collective actions (VIANNA, et al. 1999) along with empowerment for the Public Prosecuting Attorneys has made

5 These republican shortfalls must be labeled as the Brazilian dilemma of being an "Unfinished Republic". On this particular dilemma, see: FAORO, 2007.

6 On this issue, see informations available at Supreme Court international homepage: www2.stf.jus.br/ portalStfInternacional/cms/verConteudo.php?sigla=portalStfSobreCorte_en_us\&idConteudo=120199. 
visible differences in terms of claims for judicial intervention in public policies not only in cases of arbitrary omissions, though.

Whatever it is, all this represent innovations that have strengthened judicial arena in order to protecting the large constitutional conception of citizenship, as well as the constitutional design of institutions that came up with. Now, what is crucial is to observe that this outstanding empowerment of judicial arena was carried out without corresponding trade-offs with the political arena. Therefore, Brazil did not develop equivalent political mechanisms that could also strength political ties of civil society whether it is in local, whether it is in regional or in national contexts.

If we take social care services, it is easy to see how late is the Brazilian social dialogue on collective protection. Despite all endeavours carried out over the last five decades so as to overcome emergential "short term" visions - oftenly labeled as "assistentialista" - it is only from 2005 onwards that it becomes feasible create an institutionalization for the social dialog involving municipalities as well as national policies. ${ }^{7}$ Taking this into account, it is necessary to recognize that current principles of socialcare should be defined as socially based principles.

Within the healthcare policies the history of social dialog is much better. However, only from 1986 onwards emerged conditions for a social dialog in order to define health as a proper fundamental right. From the field of healthcare brought up a set of principles stemming from a wide public debate carried on during many Health National Conferences. In this context, it is of particular significance is the VIII Health National Conference (1986), which designed the features of the right to health as a universal right to be held by the society as a whole through the tax system, and the Single System of Health, as a descentralized public organization to be the main institution entrusted with the responsibility for increasingly build up these fundamental principles for any kind of policies on health (CONSELHO NACIONAL DA SAÚDE - CNE 2013, p. 26). Two years later these principles democratically discussed were set forth in the Constitution. Taking this into account, it is easy to recognize that current principles of health care should be defined as socially based principles.

Social Insurance, in turn, is quite the opposite of the health and the social care system. It has a history of extreme burocratization and centralized rulings, with very few experience with democratic decision making. Since its beginning up to

\footnotetext{
7 The Fourth National Conference on Social Assistance (2003) is known as the landmark of a new era for social care rights in Brazil. However, only in 2011 entered into force the Single System of Social Assistance through the Federal Law n. 12.435. Moreover, only in 2014, Brazil left the Hunger Map Mundi. For further informations, see the II Ten-year Plan for Social Assistance (2016-2026), avaliable at: https://blogcnas. org/x-conferencia-nacional/.
} 
the Constituent moment, Social Insurance has been treated as a matter of State. Furthermore, it has been treated over the decades as a synonym of social security. Because of the lack of social dialog on social insurance, Brazil has one extremely uneven model, with strong disparities between the public servants insurance and the general social security. Taking this into account, it is tough to recognize that current principles of social insurance could be defined as socially based principles.

\section{Judicial review in the political arena}

An international document of pivotal significance to see part of the new commitments for the Brazilian Judicial Branch, in terms of welfare rights, is the International Covenant on Economic, Social, and Cultural Rights (ICESCR), of 1966, which Brazil formally joined in 1991. ${ }^{8}$ Upon this Covenant is established one of the most important principles for the interpretation of social fundamental rights: that is the duty for progressive realisation of the Covenant, according to the available resources, which is the well known principle of the progressiveness (Article 2). The meaning and the scope of this principle must be interpreted in two senses: firstly, it indicates that not all social rights are immediately applicable; secondly, it gives raise to a duty for all Branches: ensuring progressive enhancements in the realisation of these rights (ABRAMOVICH; COURTIS 2002; COURTIS 2008; KONKAR 2009; TRINDADE 1991; KERSTENETZKY, 2012).

It is also worth noting that all constitutional interpretation of fundamental human rights might maximize the protection of the dignity of the human being, because such a principle has a preferential position. This is enshrined, for instance, in the Ethical Code of the Brazilian Magistrates which prescribes, in the Article 32, that the knowledge and the empowerment of the Judges acquire a special intensity when it is related to issues, techniques and attitudes that addresses toward the maximum protection of human rights and to the development of constitutional values. Likewise, Federal Supreme Court ruled something very similar:

The Magistrates and the Courts, in the exercise of their interpretative activity, especially in the realm of international treaties on human rights, must observe a basic principle (like that one announced in Article 29 of the American Convention on Human Rights), consistent with attributing primacy to the norm that reveals itself more favourable to the human being, in order to provide as much intense protection as possible (STF. Habeas Corpus n. 98.893 MC/SP. 09.06.09).

8 Brazil joined ICESCR via Legislative Decree number 226 (1), on December, 121991. 
Therefore, in order to understand the so called judicialization of politics in Brazil it is necessary to realize that the constitutional human rights and dignity of human being set therein have, so as to speak, a status of predominance (even though relative) within the legal reasoning. This is the ethos of the so called, citizen constitution: ensuring optimal protection for human beings through fundamental rights. Needless to say that whatever the choice made individuals or by authorities, its legal ground must be in accordance with the imperative expectations that stem from this constitutional system. Therefore, ensuring such expectations is the institutional mission of the Brazilian Judicial Branch.

This first glance suffice to realize that there are formal reasons to acknowledge that the Constitution has sparked three main new trends that have received relatively little attention from Brazilian legal and political theory so far. In order to put it briefly:

(1) A constitutional strengthening of the Judicial Branch's republican roles. That means that Judicial Branch plays a more broadly role within the checks and balances system. Nontheless, this strengthened republican role must be divided in two parts:

(1.1) Judicial Branch has become a guardian of the responsiveness: It was entitled by the Constitution to assure the borders of the Rule of Law insofar it is allowed to reviewing all sorts of abusive decisions, whether it is political or private, whether it is by action or by omission regarding binding legal commands.

(1.2) Judicial Branch has become a guardian of the progressiveness: It was entitled by the Constitution to assure optimal implementation of all fundamental rights albeit an increasing interference upon political matters might be at stake.

Evolving judicial interpretation is part of this. Actually, it is a necessary tool to carry out the control of progressiveness as well as responsiveness. Beyond any reasonable doubt, evolving judicial interpretation is not an arbitrary creation oriented by general rules. Instead, judicial interpretation evolves whenever the semantic realm of the constitutional or statute provisions ought to be updated toward better implementing the aims of a Constitution. Better yet, whenever the imperative expectations of such a system of rights ought to be. Consequently, politics are not allowed to be arbitrary in implementing the Constitutional aims in two ways: positive and negative. That is to say, Government is not allowed to take a positive action so as to issue any measure by law or decree against the Constitution (which is quite expected in democracies). By contrast, in this system, Government is not allowed to remain inert, that is, taking a negative action when the Constitution prescribe a positive action through a binding rule. Whenever this 
is the case, Judicial Branch may act as a mechanism of reviewing progressiveness, responsiveness, as well as non arbitrary answers on the part of state (or companies and persons).

Taking all this into account, it appears to be that although Brazil is a country where constitutional rights of persons are still differentiated from human rights by formal reasons, where proportionality test is not officialy embraced by the Courts, Judicial Branch is stronger than ever to intervene in the political arena based on a large set of competences. In the following discussion of Leading cases, we hope to clarify how Brazilian Superior Courts act in the realm of fundamental social rights touching sensively the political arena.

\section{Slavery}

The first Case to be analyzed in order to reveal these trends mentioned above is the Supreme Court Ruling ${ }^{9}$ on the Extraordinary Appeal n. 398.041, 2006, where, for the first time after the slavery abolition in the nineteenth century (1888), Federal Supreme Court decided a dispute upon the theme of slave labor.

9 It is worthy to clarify the Brazilian Judicial Branch organization. It is set forward on the Constitution, at Article 92. The following are the bodies of the Judicial Branch:

1 - the Federal Supreme Court;

2 - the National Council of Justice;

3 - the Superior Court of Justice;

4 - the Federal Regional Courts and the Federal Judges;

5 - the Labour Courts and Judges;

6 - the Electoral Courts and Judges;

7 - the Military Courts and Judges;

8 - the Courts and Judges of the States, of the Federal District and of the Territories.

The Federal Supreme Court, the National Council of Justice, and the Superior Courts have their seat in the Federal Capital. The Federal Supreme Court and the Superior Courts have their jurisdiction over the entire Brazilian territory. Article 95. Judges enjoy the following guarantees:

1 - life tenure, which, at first instance, shall only be acquired after two years in office, loss of office being dependent, during this period, on deliberation of the court to which the judge is subject, and, in other cases, on a final and unappealable judicial decision;

2 - irremovability, save for reason of public interest;

3 - irreducibility of compensation, with some exception regarding taxation.

On the other hand, Judges are forbidden to:

1 - hold, even when on paid availability, another office or position, except for a teaching position;

2 - receive, on any account or for any reason, court costs or participation in a lawsuit;

3 - engage in political or party activities;

4 - receive, on any account or for any reason, financial aid or contribution from individuals, and from public or private institutions, save for the exceptions set forth in law;

5 - practice law in the court or tribunal on which they served as judges, for a period of three years following their retirement or discharge 
The pivotal Opinion was held by the Justice Joaquim Barbosa, the Rapporteur of the Case, which led the Court to re-evaluate precedents and render an innovative decision based on the optimal application of the principle of inherent dignity of human being.

On January 1992, a farmer from Pará State was prossecuted for forcing several people of working in sub-human conditions, clearly in breach of the Criminal Code's Articles 149 and 203. After condemnation in a Federal Court Trial, the Regional Court of Appeal ruled the Federal Judge had no Jurisdiction for the case (rather, a State Judge would have) and overturned the entire process. Shortly after, the Federal Prosecutor insisted on his interpretation concerning the Federal Jurisdiction for such a matter, and lodged an Appeal to the Federal Supreme Court, now claiming for another review grounded in Art. 109, Parag. 5o which provides jurisdiction for Federal Judges to decide upon serious human rights violations. In accordance with the Federal Prosecutor, degradate someone to slavery ought to be seen as a crime not only against individual (which is a matter for State Courts), but also against organization of work (which is a matter for Federal Courts). Thus, the relevant constitutional issue was to know if this interpretation was correct and then which would be the Court with jurisdiction to decide such a crime: federal or state one.

Justice Joaquim Barbosa's Opinion reviewed debates over a leading case from 1979 which, for almost thirty years, guided the Supreme Court case law in terms of the meaning and contours of the competence to decide crimes against the organization of work. By 1979, the Supreme Court held that whenever the circumstances reveal serious repercussions over the general interest of workers in having a national organization of work institutions, that is to say, in avoiding its disorder, jurisdiction is to be with Federal Courts. Nevertheless, Justice Joaquim Barbosa made a proposition based on a necessity of evolving to enlarge the meaning of the so called "organization of work". This was so because the Court should implement new constitutional aims to the case so as to include in it serious damages to human being in a broader sense: that means, the right to be free, selfdetermination and dignity as a human person.

Whatever the conduct carried out within the context of work relations, if it violates the system of institutions as well as workers, by striking the more significant constitutional values, it falls into the scope of crimes against the organization of work (p. 8).

According to this strongly evolving Opinion, there is no way to interpret constitutional fundamental rights without guidance from the principle of human dignity, which was labeled by him as the axiological element that gives meaning 
to the entire constitutional framework, the very centre of gravity for the entire legal order. Having said that, Justice Joaquim Barbosa was actually stating that reasons to overcome the relative prominence of human dignity in labor contexts should be the stronggest, not only formal ones. Therefore, the Court might not surrender to formal aspects, such as that set forth in legislation that provides an absolute separation between individual freedom and organization of work, whenever facing the need to ensure responsiveness and effectiveness for the principle of human dignity.

\section{Collective labour rights}

Another very significant constitutional decision laid down by the Brazilian Supreme Court, now grounded on abusive legislative omission, is the case raised with the Writ of Injunction ${ }^{10}$ n. $670-9-E S,{ }^{11}$ whose Rapporteur was Justice Gilmar Mendes. In this case Supreme Court reviewed the civil servants constitutional right to go on strike. Supreme Court recognized, on the one hand, that civilian polices are entitled to a regulation enabling them to exercise this constitutional right and, on the other, recognized the legislative omission of the State in regulating this right in accordance with Article $37, \mathrm{VII}^{12}$ of the Brazilian Constitution.

The innovative aspect of this ruling lies on the fact that, for the first time, Supreme Court has fulfilled the lack of Laws by delivering a very decision with general effects. Akin to a Law, this decision has enabled all civil servants to the exercise of the constitutional right, although the lack of a statute passed by the legislative body. The ultra partes effects of the decision touched every civil servant in Brazil. More precisely, Supreme Court has extended the effects of a general law to go on strike (called "The private sector Law to strike") to civil servants and edited, accordingly, several particular rules concernig federal judges' jurisdiction in this particular circumstance to match particularities for municipal, state and federal civil servants - thus, putting apart the Labor Judicial Branch.

Many elements of an arbitrary omission from Legislative Branch were pointed out by the Supreme Court. We further note that, despite of all appearances of a careless judicial activism, it is hard to deny the features of an exemplary self restraint that was raised with this ruling. For instance, in several earlier and similar

10 According to Article 5, LXXI, a writ of injunction will be granted whenever the lack of a ruling norm makes the exercise of rights and constitutional freedoms and the prerogative inherent in nationality, sovereignty and citizenship unviable.

11 Ruled on October 25th, 2007, in a "en banc" Court.

12 Art. 37 , VII - The right to strike will be exercised in the terms of in the limits established on specific law. 
cases, the Court has insistently notified Legislative Branch to deliver satisfactory rules for this circumstance; in many others, the Court has recognized the binding effects of the constitutional guarantee called Writ of Injunction, that means that decions laid down on this type of proceeding ought to be observed by Legislative Branch; in still several others, the Court recognized the abusive omission and declared such a circumstance by establishing Legislative Branch's culpable delay.

This is a typical decision that, for many reasons, highlights the republican role of the Judicial Branch as well as its role of guardian of the responsiveness of the State. In summary, it was a Ruling by which it became pretty clear that arbitrary exercise of power is unbearable, whether it is by positive or by negative action. Moreover, it was affirmed that Brazilian Republic cannot survive with the absence of good constitutional reasons among the Branches. Therefore, Judiciary ought to intervene by fulfilling the lack of rules whenever an abusive omission on the part of the Legislative Branch causes a violation of a constitutional fundamental right.

\section{Cccess to medicines: blocking public budget and joint responsibility of federal entities}

The choice of National Constituent Assembly (1988) of enshrining the right to health as an universal and fundamental one is another indication of the attempt to enlarge the right to be treated as a human being in Brazil. Therefore, both Supreme Court as well as Superior Court of Justice have recognized the judicialization of the right to health as a phenomenon that will involves all civil society. Accordingly, many judicial innovations in this field have to do with the right of access to medicines as well as the right to hospital treatment in serious circumstances. Thus, basically healing measures.

Many of these decisions, however, represent drastic measures oftenly involving intervention on budgetary planning. For instance, Superior Court of Justice has repeatedly stressed that the Civil Procedure Code allows Judges evaluate, in some concrete cases, the most appropriate way to make fundamental rights effective. Such an understanding also allows critical rulings where negligence on the part of Executive Branch might be resulting in serious damages to health or life. Furthermore, Superior Court of Justice has also held that whenever there is a dispute between the fundamental right to health and immunity of public assets to private seizure, the former prevails over the latter. This is the case when the acquisition of medicines is urgent. ${ }^{13}$ Any refusal on the part of the State

13 SCJ. REsp 832.935, Reporting: Justice Teori Albino Zavascki, DJ 30.6.2006 
of providing a medicinal drug of essential use, moreover, available at the public system of health and whose lack risks the life or health, constitutes a breach of the Constitution. On the one hand, this is so because life and health are goods strongly protected by the Charter, on the other, because such circumstances are extremely serious as well as urgent. These are the reasons why rulings ordering a delivering of medicinal drugs have been often upheld by the Court. Accordingly, it is fair to state that this is, to some extent, a recognition that government authorities do not hold the monopoly toward evaluating convenience and opportunity in public expenditure field. Consequently, even if a Court order the blockin of a state's bank account, this type of measure, which is equivalent to seizure of private property, is meant as part of the rule set out in Art. 301 of the Civil Procedure Code. Judiciary is therefore supposed to be legally allowed to determine such special measures for implementing an urgent protection for health or life.

On the part of the Supreme Court, it has repeatedly held that in exceptional circumstances the order to deliver drugs to people without economic resources to buy them can be based upon a direct interpretation of the Constitution because "no interpretation of programmatic constitutional rules are allowed to make it an inconsequential constitutional promise". ${ }^{14}$ As for the joint responsibility of Municipalities, States and Union Federal, Supreme Court has already set that it is consistent with the draft of a Precedent which proposes binding effects to judicial understandings of joint responsibility of the Federation entities in implementing health actions.

Conversely, although there are constitutional provisions establishing formal duties for all federation entities so as to implement the right to health, this matter oftenly raises sensitive issues such as doubts on constitutional distribution of competences, not only between the Branches, but also between federal political units; not to mention the complex issue regarding the budget availability of the State. Nevertheless, the Supreme Court has convicted jointly Municipalities, States and the Federal Government to provide required health treatments based on Art. 23, $\mathrm{II}^{15}$ of the Constitution as well as upon the Federal Law n. 8.080/90, Art. $7, \mathrm{XI}^{16}$

14 FSC, Extraordinary Appeal n. 232.335-RS, Rapporteur: Justice Celso de Mello, 01.08.2000.

15 Article 23. The Union, the states, the Federal District and the municipalities, in common, have the power... II - to provide for health and public assistance, for the protection and safeguard of handicapped persons;

16 Article 7. Public actions or services on health, private services hired or under cooperation agreement to this purpose, which are part of the Unified Healthcare System (UHS), ought to be developed according to the guidelines set forth on Article 198 of the Federal Constitution, observing the following principles: XI combine financial, technological, material and human resources from Federal Government, States, Federal District and Municipalities so as to provide services and assistance in health for people; 
In an remarkable case, ${ }^{17}$ the 5 th Federal Regional Court convicted jointly the Union, the State of Ceará as well as the municipality of Fortaleza to provide a very particular medicine drug to a young girl with a disease called Niemann-Pick type $\mathrm{C}$ so as to enable her survival ass well as to improve her quality of life. As a consequence, federal government appealed the decision to argue that the Court order simply breached the principle of Separation of Powers. Furthermore, likewise inferior rules of the Unified Health System - SUS, as well as simply dismissed the Administration's exclusive role to define its policies, which would represent a improper interference of the Judicial Power to the competencies related to policies. The Supreme Court, however, has considered that the Federal Government had no reason. Concerning the possibilities for Judicial Power interventions, the Court invoked a previous decision handed down in ADPF $45 \mathrm{MC} / \mathrm{DF}$, so as to state that in case of unreasonable State omission, it is fair the judicial intervention.

As for the argument that the joint conviction of the Union, States and Municipalities would cause disorder to the federal constitutional system, the Court held that previous decisions ${ }^{18}$ made clear that health is a national matter, then the existence of this joint responsibility in the field of health is part of the constitutional duties of the State as a whole. Summarily, all federated units are obliged to build a model of cooperation and coordination of joint actions in the field of public health.

\section{Equipment and materials for hospitals}

Another leading case that is worth discussing comes from the Superior Court of Justice (SCJ) also in the field of Public Health. ${ }^{19}$ This case dealt with the provision of equipment and materials for a universitary hospital as an obligation of the State with the universal fundamental right to health. In the decision, the Supreme Court held that social rights might not be conditioned by the mere administrator's will.

According to Min. Humberto Martins, Rapporteur, the principle of Separation of Powers was originally designed to protect fundamental rights. Hence, it might not be used as an impediment to the realization of social rights, which are also fundamental constitutional rights in Brazil. Conversely, a correct interpretation of the argument of this principle requires that all Powers operate within the limits granted by the law. Whenever one of the Powers strays from the purpose of the

17 STA AgR 175 / EC, Rel. Min. Gilmar Mendes, 17.3.2010, Supreme Court. Injunctive relief suspension n.175, Decision of 17.03.2010.

18 FSC. RE 195192 / RS, 31.3 DJU .2000 and RE 255627 / RS, DJU, 23.2.2000, RE/RN 566.471, DJE of 7.12.2007

19 SCJ. REsp 1041197-MS, judged on 08/25/2009. 
Law, it ought to be seen as a violation of the Rule of Law. In such cases, the Judicial Branch intervention so as to protect the Rule of Law is nothing more than a constitutional duty. In short, whenever the government abuses of its competences (beyond or less) the principle should not apply. ${ }^{20}$

\section{Day-care centers and pre-schools}

A further leading case of significant consequences is the Appeal that upheld a decision from a Trial Court that obliged the municipality of Santo André, São Paulo State, of creating new posts in municipal day-care centers and preschools for children, subject to daily fines. The Appeal lodged by the municipality of Santo André argued, in short, that local government is entitled to formulate policies by assessing convenience and oportunities of the circumstances. Thus, irrespective the matter, it would be a serious infrigement to the constitutional model of separation and distribution of Powers, if Judiciary cross the line of a strict examination of the legality and legitimacy of government actions.

The first Chamber of the Superior Court of Justice did not recognize this perspective, though. This is so because the administrator has no discretion in the face to constitutionally enrishned rights.

Infant education to children of up to 5 (five) years of age in day-care centers and pre-schools is enshrined in constitutional provisions as well as reproduced in Article 54 of the Child and Youth Statute. (...) It seems unreasonable that inferior rights set forward in regulations such as circulars, ordinances, interim measures as well as in ordinary laws may have immediate effect, while constitutional rights, inspired by the highest ethical and moral values of the nation, are to be relegated to a second place. (...) The right to infant education in daycare centers and pre-schools is established in a so strong manner precisely because it is a duty whose obligor is the State.

(...)

This is a duty, however, that state does not have to support by acommodating children in private schools. What the sovereign State promises for itself or for its delegates is fulfilling the duty of education

20 SCJ, REsp 1041197-MS. Rapporteur: Justice Humberto Martins, 25 August 2009. Also see: FSC, ADPF 45DF, DJ 4.5.2004; AgRg at RE 595.595-SC, DJe 29/5/2009; From SCJ: REsp 575.998-MG, DJ 16.11.2004, REsp 429.570-GO, DJ 22.3.2004. 
through the offer of public day-care centers and pre-schools for children. ${ }^{21}$

\section{Social insurance rights}

Within this matter, there are two cases that drawn much critical attention. At a first glance, both would have delivered non-evolving judicial orientations as well as no protection for progressivenes. Nevertheless, both tell us much more than this.

\subsection{Taxation on pension income}

In deciding the Direct Action of Unconstitutionality n. 2.010 (1999), Federal Supreme Court has forbidden taxation on civil servants' pension. Thus, only after the Constitutional Amendment n. 41, on December, 19th 2003 it became possible to tax such incomes. ${ }^{22}$ On the part of Petitioners, they alleged that the State was responsible for violation of the right to property, the right to judicial protection, and the right to a progressive development of economic, social, and cultural rights. In this respect, the State alleged that Constitutional Amendment n. 41/03 was motivated by the social security deficit and the increasing of the life expectancy for Brazilian citizens, as well as the need to maintain the financial balance of the State and to ensure the right of all citizens to receive a pension. Therefore, it was a fair and reasonable measure. According to the Ruling n. 3.105, 2004 (Direct Action of Unconstitutionality) the Supreme Court held that in Brazil there is no any rule protecting public servants' pension against any taxation. More precisely, there would not exist an absolute immunity for any kind of incomes and revenues from taxation.

In a first glance it appears to be contradictory to the welfare rights, however, in this particular case taxation might be recognized as an appropriate tool of enhancing social welfare. The decision was based on the financial informations upon the fiscal expenditures. Such informations explained the remaining large

21 SCJ. RE n. 575.280 - SP. Rapporteur: Justice José Delgado. Rapporteur for the Ruling: Justice Luiz Fux. First Chamber. 2 September 2004.

22 It was decided at the ADIs 3.105 and 3.128, reported by Justice Ellen Gracie, En banc, DJ 18.2.2005. Also, Al-AgR 699.887, Rapporteur: Justice Ricardo Lewandowski, First Chamber, DJ 22.5.2009; RE-ED 504.068, Rapporteur: Justice Cármen Lúcia, First Chamber, DJ 26.6.2009; RE-ED 593.586, Justice Joaquim Barbosa, Second Chamber, DJ 29.10.2009; RE-ED 392.121, written by Justice Celso de Mello, Second Chamber, DJ 25.6.2010. 
differences existing between the pensions paid to the servants of the State and all the other Brazilians. So it was not difficult to infer that huge disparities were taking place, and that a significant part of civil servants received very high pensions and incompatible with the state paying availability. Thus, the changes allowed taxing higher pensions and thereby increased the financial protection of social benefits.

\subsection{Survivors vs tempus regit actum principle}

At the Ruling n. 415.454-4 (Extraordinary Appeal) dismissed on 2007, the Supreme Court issued another of its significant and controversial decisions on pension matters. It was established rules on the effects of pension law over time and asserted a very controversial version of the so called principle tempus regit actum. Here the Court held that reviewing the amounts paid by Social Security to holders of death pension benefit should be strictly balanced with the principle of legal certainty (Art. 5. XXXVI, Constitution) as well as the budget availability of the Brazilian state. These are limits set out in Article 195, $\S 5$ of the Constitution which prescribe that: No benefit or service of social security may be created, increased or extended without a corresponding source of full funding. The Court addressed an Appeal filed against a Ruling delivered by the Court of Appeal from Santa Catarina State. Based on the principle of equal protection, such state Court decided that pension received by a survivor ought to be readjusted on the basis of the parameters laid down in Art. 28 of the Federal Law n. 9.032, 28 April 2005. Thus, the constitutional issue set forth in the Appeal was to know whether the new parameters to calculate pension benefits would reach all benefits already paid by Social Security or only new ones. In other words, these new ones would be all those beneficiaries who have not received such a benefit yet, and henceforth will receive it from April, 28th 2005 onwards, that is, from the date of the enactment of the aforementioned Law. Supreme Court, on its part, held that Trial Courts when ordered readjustment for pre-existing benefits grounded on the new Act $^{23}$

23 Federal Act No. 9.032, dated 28 April 1995, stated in its Article 28 that the value of the benefit annuity, including one governed by a special norm and one derived from a work accident, except for family benefits and maternity benefits, will be calculated on the basis of the baseline salary. This same law revoked Article 75 of Act 8.213, dated 24 July 1991, which stated: the monthly value of a survivor's benefit will be: a) constituted by a share, relative to the family of $80 \%$ (eighty per cent) of the value of pension that the insured received or had the right to had he been retired on the date of his death, plus some shares of $10 \%$ (ten per cent) of the value of the same pension for his dependants, up to a maximum of 2 (two); and b) $100 \%$ (one hundred per cent) of the baseline salary or of the contribution salary in force on the day of the accident, whichever is more beneficial, in the case when death takes place as a consequence of a work accident. The conflict arose because the new Act admitted, expressly, that the benefits of the annuity should be calculated on the basis of the baseline salary. In this way, the new more beneficial federal Act altered the basis of 
incorrectly applied the principle of acquired rights within the welfare rights. Conversely, benefits ought to be calculated according to what is established in the legislation in force on the date on which the right is tecnically acquired (tempus regit actum). New laws, thus, benefit only new situations. In short, the Court held that on matters concerning pension rights, similarities between past and present situations are not sufficient to justify progressive interpretations in favour to the former. That is to say: it does exist a clear limitation for progressiveness within the field of social security: availability of funds.

\section{Conclusions}

What is the limit of this model? What is the philosophy of social security that stem from it?

Firstly, Judicial Review has played a central role in the political debate on social security over the last three decades. The judicial control of all the welfare rights in terms of responsiveness by the public policies as well as of their progressive implementation, seemed to have been guided a) by a broad conception of binding normativity, not much attached with legal rules; b) by an increasing consideration of proportionality issues, albeit without an uniforme manner to do so; c) by an increasing influence from constitutionalism and human rights approach, however in an uneven manner according to the fields of law; e) by a new view upon the political role of Judicial Branch.

To some extent, Brazilian Courts appear to be guardians of a supposed morality set forth in the Constitution. If in the past Courts were only veto players within the System of Powers, today it is not the case anymore. Perhaps it would be also fair to state that such strong transformation of the Brazilian system of checks and balances, which strongly touched the way social conflicts came to be solved, is underpinned on five characteristics: (1) existence of a long and detailed constitutional Bill of Rights with a multidimensional vision of fundamental rights; (2) recognition of a strict connection between lack of citizenship and lack of dignity of the human being; (3) a wide spread model of constitutional judicial review system, once all Judges play the role of constitutional guardians, not only Supreme Court; (4) particular constitutional Actions allowing Public Prosecuting Attorneys claim for Judicial intervention in public policies in case of arbitrary omissions or in classical cases of exceeding constitutional limits; (5) Public overture of the Supreme Court to television, public hearings and amicus curiae.

From the point of view of accumulated experiences with this model, it seems to reveal its formula: it is a model of protecting fundamental rights highly dependent on the Judicial Branch as well as slightly dependent on social democratic 
institutionality. Mechanisms of control of responsiveness are concentrated primarily on the Judicial Branch, not in civil society. Therefore, we maintain that despite of the massive presence of social security rights in the Constitution, what eventually brought up from the Constituent Assembly was not properly a social-democratic system, that is to say, one that provides strong social control mechanisms of responsiveness to civil society, whether it is parties, unions, associations, universities, churches, NGO and alike.

Furthermore, civil institutions capable to controlling public policies on social security, even though within regional or local interests have not been duly regarded as a major matter for social protection. Likewise, political mechanisms invented to promote dialogue (or competition) between federal entities are clearly insufficient to join forces with civil society. Moreover, political control of key economic institutions, such as Public Prosecution, Court of Auditors, Central Bank or Public Banks, none of this have received innovative formulas of social dialogue. In addition, the shortfalls in terms os social engagement also reach the key institutions of the system of economic and social rights. As previously stated on this study, Brazil has opted for an universal health care system. Notwithstanding this is not yet a system able to creating citizenship identities for all. Quite on the contrary, it is still conceived as a system for needy poor people. The Brazilian middle class practically does not search for the public system of hospital care and pharmacies. After these years of experience, public health system, in spite of visible enhancements particularly during the last 15 years, is not yet a mechanism of equal protection for all.

On the part of social care services, and in spite the very relevant innovations with the so labeled Bolsa Familia Program, which has decreased significantly extreme poverty in Brasil, the few significant improvements towards a more social controled direction of policies focused on the poorest are very recent and have not been properly institutionalized. In turn, Social Insurance democratization is not a reality whatsoever.

Thus, as a matter of conclusion we may affirm that the Brazilian model of social security is strongly established in Constitution, which also strengthened the Judicial Branch as a guardian of its responsiveness. However, this is not a model with an explicit philosophy of social protection. It is neither a social-democratic model because of the insufficient development of civil society mechanisms, nor a liberal model because of the heavy presence of the state as provider of welfare.

If a social cohesion was achieved during the years 1985 up to 1993 and if a certain philosophy of social security emerged up from the Constitution, over the last years Brazilian democracy did not renew the alliance of classes to confirm that early model or to improve it. That is why, to a certain extent, it can be said that over the course of the last three decades Brazil failed to advance a crucial issue: the 
political agreement on a model to the expansion of individual freedom, resilience of its communities, sustainability of its model of production and consumption. The lack of a philosophy for development, resilience and social protection is clear. Brazil is for while a very uneven society with an inspiring set of fundamental rights established in its Constitution, which is protected by a strong Judicial Branch. Nevertheless, it is deprived of an updated political philosophy on the social protection necessary for the upcoming challenges. On one hand, this is one more sign of the underdevelopment of this very dynamic society, on the other, it is also an invitation to think.

Recebido em: 20.09.2016.

Pareceres: 20.10.2016 e 25.10.2016.

Aprovado em: 13.12.2016.

\section{Direitos sociais constitucionais sem uma filosofia de segurança social}

Resumo: O direito constitucional brasileiro tem uma concepção ampla e multidimensional dos direitos fundamentais. E os assim chamados direitos de bem-estar social fazem parte deles. Tais direitos não são apenas formalmente encontrados no Título II, que é a Carta de Direitos Fundamentais, mas também são protegidos por ações constitucionais específicas que foram estabelecidas como meios para a implementação desse tipo de direitos. Os direitos de proteção social como a saúde, pensões e assistência social para os mais vulneráveis gozam, portanto, de uma posição preferencial no âmbito do sistema brasileiro de direitos constitucionais. Este artigo sustenta que, apesar da adoção de uma forte concepção constitucional de direitos de segurança social, a falta de uma filosofia de estado de bem-estar consistente e coerente ao lado do sistema de regras constitucionais prejudica gravemente a implementação progressiva desses direitos, bem como desencadeia significativas divergências no seio da sociedade. Na primeira parte o manuscrito busca esclarecer as causas desta circunstância de reconhecimento da saúde, assistência social e seguro social como direitos fundamentais, sem o equivalente reconhecimento da segurança social como um autônomo direito humano. Depois disso, o artigo se dedica particularmente à judicialização dos direitos sociais, de modo a explorar questões que podem iluminar esse problema. Como conclusão, o artigo destaca o paradoxo da falta de uma filosofia adequada de segurança social num contexto de forte proteção constitucional da saúde, assistência social e previdência.

Palavras-chave: Segurança social. Estado de bem-estar. Direitos sociais. Brasil.

\section{References}

ABRAMOVICH, V.; COURTIS, C. Direitos sociais são exigiveis. Trad. L. C. Stephanov. Porto Alegre: Dom Quixote, 2011. 
CASTRO, Carlos A., and João Batista LAZZARI. Manual de Direito Previdenciário. RJ: Forense, 2015.

ESPING-ANDERSEN, G. The Three Worlds of Welfare Capitalism (e-book ed.). Princeton: Polity Press, 2012.

FAORO, Raymundo. A República inacabada. São Paulo: Globo, 2007.

FLEURY, Sonia. "A seguridade social e os dilemas da inclusão social." RAP - Revista de Administração Pública 3, no. 39 (Mai/Jun 2005): 449-469.

FLEURY, Sonia. Estado sem cidadãos: seguridade social na américa latina [on line]. Rio de Janeiro: Fio Cruz, 1994. Disponível em: SciELO Books.

HEREDERO, Anna Gomez. Social security as a human right. Strasbourg: Council of Europe, 2007.

ILO - International Labor Organization. Social security and the rule of law. International Labour Organization, Committee of Experts on the Application of Conventions and Recommendations. Geneve: ILO, 2011.

ILO - International Labor Organization. Social Security: a new consensus. International Labor Organization. Geneve: ILO, 2001.

ILO - International Labor Organization. World Social Protection Report: 2014/2015: building economic recovery, inclusive development and social justice. Geneve: ILO, 2014.

IPEA. Políticas Sociais: acompanhamento e análise: 20 anos da Constituição Federal. Brasilia, DF: IPEA, 2008.ISSA. Social Security Coverage extension in the BRICS. ISSA, 2013.

KERSTENETZKY, C. L. O Estado do Bem-Estar Social na Idade da Razão. Rio de Janeiro, RJ: Campus, 2012.

KONKAR, P. The evolution of international and european law in the field of social rights. Revista europea de derechos fundamentales , 193-204, 2009.

LANGFORD, M. Social Rights Jurisprudence: emerging trends and comparative law. Cambridge, Inglaterra: Cambridge University Press, 2009.

UNITED NATIONS. Human Development Report - 2015. UNDP, 2015.

PIOVESAN, Flavia. Direitos humanos e o direito constitucional internacional. São Paulo: Saraiva, 1996.

SAVARIS, J. A. Uma teoria da decisão judicial da Previdência Social: contributo para superação da prática utilitarista. Florianópolis: Conceito, 2011.

SARLET, Ingo Wolfgang. A eficácia dos direitos fundamentais: uma teoria geral dos direitos fundamentais na perspectiva constitucional. 11a. ed. Porto Alegre: Livraria do Advogado, 2012.

SARLET, Ingo Wolfgang, MARINONI, Luiz Guilherme, MITIDIERO, Daniel. Curso de Direito Constitucional. São Paulo: Saraiva, 2016. 
STRAPAZZON, C. L. Âmbito de proteção de direitos fundamentais de seguridade social: Expectativas imperativas de concretização . In I. W. SARLET, \& C. L. Strapazzon, Constituição e Direitos Fundamentais. Porto Alegre, RS, Brasil: Livraria do Advogado, 2012.

STRAPAZZON, C. L. Primeiros elementos para uma teoria constitucional do direito humano fundamental de segurança social. Joaçaba, Brasil: Editora Unoesc, 2015.

STRAPAZZON, C. L., SERRAMALERA, M. B. Direitos Fundamentais em Estados Compostos. Chapecó, SC: Editora Unoesc, 2013.

TRINDADE, A. A. Tratado de direito internacional dos direitos humanos (Vol. I). Porto Alegre, RS: Sergio Antonio Fabris, 1997.

UNRISD - United Nations Research Institute for Social Development. Transformative Social Policy. ONU, Research Institute for Social Development. Geneve: ONU, 2006.

VIANNA, Luiz Verneck, CARVALHO, M. A. R.; MELO, M. P. C. e BURGOS, M. B. A judicialização da política e das relações sociais no Brasil. Rio de Janeiro, RJ: Revan, 1999.

Informação bibliográfica deste texto, conforme a NBR 6023:2002 da Associação Brasileira de Normas Técnicas (ABNT):

STRAPAZZON, Carlos Luiz; TRAMONTINA, Robison. Constitutional social rights without a social security philosophy. Direitos Fundamentais \& Justiça, Belo Horizonte, ano 10, n. 35, p. 227-251, jul./dez. 2016. 